\title{
Just-in-Time or Just-in-Case? Time, Learning Analytics, and the Academic Library
}

Karen P. Nicholson, Nicole Pagowsky, and Maura Seale

\begin{abstract}
In this essay, we explore the timescapes of library learning analytics. We contend that just-intime strategies, a feature of late capital modes of production, New Public Management, and future-oriented risk-management strategies inform the adoption of learning analytics. Learning analytics function as a form of temporal governmentality: current performance is scrutinized in order to anticipate future performance and prescribe just-in-time interventions to mitigate risknot only for the student but also for the institution. Ultimately, we argue that using time as a lens to examine discourses surrounding library learning analytics reveals the temporalities reproduced in this discourse, which obscures questions of power, politics, and history. In describing what the future $i s$, rather than what it could or should be, this discourse erases our ability to shape our futures, and our responsibility for so doing.
\end{abstract}

The trouble with our times is that the future is not what it used to be. (Becker 1979, 409)

\section{Introduction}

In this essay, we explore the timescapes (Adam 1998) of library learning analytics. Adam (1998) introduces the concept of timescape to underscore the interrelatedness of time, spatiality, and matter and the importance of context in our experience of time. We contend that just-in-time strategies, a feature of both late capital modes of production and New Public Management, and future-oriented risk-management strategies inform the adoption of learning analytics. Learning analytics function as a form of temporal governmentality: current performance is scrutinized in order to predict future performance and prescribe just-in-time interventions to mitigate risk (Williamson 2016) - not only for the student but also for the institution. Aversion to risk is a key feature of bureaucratic organizations such as academic libraries (Lynch 1979). Producing the student as future worker, alumnus, and donor secures the reputation and financial future of the university and the place of the library within it. These practices and strategies not only restructure the timescapes of academic library work, they also enroll the library into the university's globalizing agenda (Nicholson 2019a).

Time "is an invisible and unremarked relation of power" (Sharma 2014, 13). Using time as a lens therefore affords new insights into the impacts of neoliberal globalization on higher education (Bansel and Davies 2005; Clegg 2010; Giroux and Searls Giroux 2004; Menzies and Newson 2007; Walker 2009; Ylikoji and Mäntylä, 2003), academic libraries, and the work of librarians (Drabinski 2014, 2016, 2017; Nicholson 2016, 2019a, 2019b). ${ }^{1}$ Drawing on this literature, in this

\footnotetext{
${ }^{1}$ Neoliberalism is an array of political economic practices based in the belief that "society works best when the people and the institutions within it work or are shaped to work according to market principles" (Spence 2015,3). These practices share a number of characteristics with classical liberalism, including a view of individuals as rational, self-interested subjects; free market economics; and a commitment to the principles of laissez-faire and free trade (Harvey
} 
essay, we argue that a temporal approach allows us to see the profession's engagement with learning analytics as a strategy largely motivated by anxiety and self-interest intended to secure the future of the library. We seek to unpack, as Watters describes it, "the history of the future" of library learning analytics. Describing educational technology, Watters writes, "The rich and fascinating past of education is forgotten and erased in an attempt to tell a story about the future of education that emphasizes products not processes, the private not the public, 'skills' not inquiry" (2015, n.p.). Library learning analytics, like other educational technologies, are proclaimed to be the future of higher education writ large, while personal histories, institutional context, and the politics of higher education are swept aside.

This paper is divided into three parts. In the first part, we explore the timescapes of higher education, academic libraries, and librarianship. We contend that as a profession, librarianship is informed by the temporal strategies of cost accounting, scientific management, and just-in-time service models. Time serves as a means to demonstrate value and professionalism, a means of accounting, and a form of self-regulation (Bossaller, Burns, and VanScoy 2017; Hicks 2014; Hicks and Schindel 2016). Moreover, within the context of higher education as a space through which the neoliberal global project is mediated (Robertson 2009), time also serves as a strategy by which the academic library seeks to manage risk and secure its future. These various timescapes produce and are productive of particular political agendas, curricular models, and pedagogical strategies, essentially laying the groundwork for the implementation of learning analytics. In the second part, we use time as a lens to explore mainstream library and information science (LIS) professional documents and discourses on learning analytics to suggest that these documents and discourses function as risk technologies that work to render the future as already known. The ability to direct the future, as well as the necessity for taking responsibility for what it looks like are erased; instead, library learning analytics and neoliberal notions of library value appear as the only possible future. In the third and final part, we consider the ways that library learning analytics play out in real time, enacting particular-temporal-neoliberal subjectivities, those of quantified, flexible, and resilient learners and future entrepreneurs and working against social justice movements in higher education.

2007; Olssen and Peters 2005). In contrast to classical liberalism, however, in a neoliberal paradigm, the state takes a deliberate role in engineering the conditions, laws, and institutions necessary for the operation of the market (Harvey 2007). Neoliberalism structures domestic and global economic relations and introduces competitive market relations into all arenas of public and private life, privileging the individual as a self-interested economic agent and blurring the boundaries that exist between market/state, public/private, and individual/social (DeVault 2008; Harvey 2007; Olssen and Peters 2005).The primacy of the individual within neoliberal frameworks works against social justice, which requires putting aside self-interest in the pursuit of some larger shared cause, such as equal access to education or environmental protection (Harvey 2007). 


\section{The Timescape of Higher Education, New Public Management, and the Global Knowledge Economy}

Time shapes the public mission of the university, impacting research agendas, curricula, and pedagogy (Giroux and Searls Giroux 2004). As a result, the multiple, sometimes contradictory societal roles and functions of the university as an institution of culture and inquiry, a driver of economic growth and innovation, and a transnational corporation manifest themselves in a variety of organizational timescapes: "While academic capitalism and globalization intersect and shape higher education institutions, pre-modern time, clock-time, and global time are all present and interact with each other in conflicting and disharmonious ways" (Walker 2009, 505). On the one hand, under New Public Management (NPM), an array of doctrines and practices introduced in a large number of OECD countries in the 1980s as a means of fostering efficiency and accountability in the public sector, ${ }^{2}$ time in the university has become accelerated and intensified (Bansel and Davies 2005; Giroux and Searls Giroux 2004; Menzies and Newson 2007; Walker 2009; Ylijoki and Mäntylä 2003). On the other hand, the production of students as future knowledge workers, knowledge mobilization, and innovation, key functions of the contemporary university, are accompanied by future-oriented, competitive strategies intended to secure a place for the university in the nebulous and chaotic space of the global higher education sector (Clegg 2010; Matus and Talburt 2015; Robertson 2010; Usher and Edwards 2007).

The university's timescape is produced by and productive of particular curricular strategies and pedagogical approaches, including modularization, online learning, and just-in-time service delivery (Giroux and Searls Giroux 2004; Hartman and Darab 2012; Hood 1991; Moss 2006). These strategies and approaches, ostensibly used to promote flexibility and choice for students, also serve to maximize profits by intensifying the time of the curriculum and circumventing the space constraints of the physical campus (Moss 2006). For example, trimesters replace semesters, asynchronous online courses occur outside of class time and classroom spaces, and limited office space is shared by several adjunct faculty. They also enact new temporal subjectivities. Payne and Wattchow describe how "slow," immersive pedagogies, such as experiential learning, and face-to-face interactions are being "diminished," "via the disembodiment, displacement, disembedding, and decontextualization" of "fast, take-away, virtual, globalized, download/uptake versions of electronic pedagogy" $(2009,17)$.

\section{Time and the Academic Library: Just-in-Time and the Present-Future}

The management of work and the discipline of workers requires the management of time (Adam 1990). Librarians use time as a marker of change, a means of counting and accounting, and an indicator of professionalism (Bossaller, Burns, and VanScoy 2017; Hicks 2014; Hicks and Schindel 2016). Because time is often used to measure service quality (e.g., wait times), it also serves as a form of self-regulation and discipline (Bossaller, Burns, and VanScoy 2017).

\footnotetext{
${ }^{2}$ New Public Management can be considered the mechanism by which broader neoliberal discourses and values are operationalized in higher education. Central to NPM are corporatization, privatization, deregulation, cost-cutting, management through objectives, and professional administrators (Hood and Jackson 1991). For an overview of New Public Management, see Hood (1991) and Hood and Jackson (1991).
} 
Time is also as an important mechanism through which the library demonstrates its value and relevance. In the 1990s, the advent of the 24/7 environment was lauded as evidence that the academic library was in sync with the global knowledge economy (see, e.g., Widdicombe 2004). Today, through the creation of new digital services and spaces, the library seeks to portray itself as an innovative, future-focused partner in the research enterprise (Brown et al. 2014; ClosetCrane 2011; Mirza and Seale 2017; Nicholson 2019a; Vyhnanek and Zlatos, 2011). At the same time, bureaucracies, by their very nature, seek to reduce uncertainty and manage risk by setting out to predict, and control, the future. In this way, the "value agenda," the need for the academic library to demonstrate efficiency, accountability, and return-on-investment, is marked by two competing and conflicting temporal orders. The first is the accelerated and compressed timescape of just-in-time service models; the second is the timescape of a present-future, whose primary value lies in staving off the risk of a library-less future. This present-future is characterized by its flatness; outside of history and context, it denies the possibility of politicsand, therefore, agency and resistance. These two timescapes are outlined below.

\section{The Professionalization of Librarianship: From Scientific Management to Just-in-Time}

Librarianship has an interesting, yet underexplored, relationship to time as governmentality that stems from the specific context within which librarians become professionalized (Drabinski 2016), the nature of librarianship as a feminized profession (Harris 1992; Gaines 2014), and the structure and values of the library as a bureaucratic organization and workplace (Lynch 1979). Kont (2013) traces the history of scientific management, associated with Taylor's time and motion studies, and cost accounting in American libraries from 1857 to 1960. With the expansion and growth of libraries in the second half of the nineteenth century, work became routinized and standardized, and the need for "numerous educated employees who would be willing to work for an average or low salary emerged" (Kont 2013, 227). When librarian as pinkcollar service provider replaced librarian as (male) scholar toward the end of the nineteenth century, time became the measure of the profession: time and motion studies were not only used to measure individual performance but also to determine standards for performance, working conditions, and training (Kont 2013, 236).

At the same time, as libraries grew and developed into service centers, they were asked to justify their costs to their parent organizations. Cost accounting and time and motion studies provided a means of increasing efficiency, effectiveness, flexibility, competition, and control. (These are also goals of New Public Management, as we will see below.) By the 1950s, many large academic libraries in the US used scientific management, including time and motion studies and cost accounting, to maximize efficiency and reduce costs (Lynch 1979).

In the late 1970s, the shift from Fordism to flexible accumulation (Harvey 1989) ushered in the era of just-in-time lean production, made possible by new information and communication technologies (ICTs). Through the lens of time, lean production can be seen as an extension of scientific management rather than its replacement (Hermann 2015; Nishimoto 2002): as a result of the acceleration and intensification of work, waste (of time) is eliminated from the production process as a whole, thereby increasing efficiency and profits. While the goals of Taylorism and Fordism were to improve individual work processes and workflows, respectively, under lean 
production, "the new goal was to accelerate the entire factory" by breaking down and simplifying tasks in order to reduce the number of workers needed (Hermann 2015, 71). Moreover, through the process of kaizen, workers are responsible for using their knowledge and expertise not only to improve the production process but also to rationalize their own work and that of their colleagues (Hermann 2015). In this way, the use of time, technology, and teams as key mechanisms for coordinating, accelerating, and intensifying work, all features of postFordist organizations and just-in-time production, facilitates self-regulation and surveillance (Nishimoto 2002).

The LIS literature suggests that as a result of this shift, libraries also experienced technological acceleration, although such acceleration is not mentioned in connection to just-in-time servicedelivery models. For example, in a 1978 issue of Library Trends, Becker provides the following description of the impact of technological change, the networked environment, and the "information explosion" (410) on the library:

Change is not new to libraries, of course, but what is new is the collapsed timescale of change. In the past change was faced as it happened, but lately social and technological alternatives have occurred at so great a rate that change must be dealt with continuously. The order of change is entirely different from anything which came before. (409)

Automation and networks afforded new means to raise productivity and cut costs (Becker 1978). References to just-in-time appear as of the 1990s, when the Web afforded new ways to reduce the cost of serials acquisition and article delivery (Carrigan 1996; Widdicombe 2004). In this way, the academic library became embroiled into the 24/7 hyperaccelerated time of the "network society" (Castells 1996).

Discourses of change remain pervasive in LIS literature, tying the academic library to accelerated and intensified time. Consider, for example, the Association of Research Libraries' (ARL) Strategic Thinking and Design Initiative, the result of members "taking to heart" the challenges of "working in a new normal - a world of constant change brought upon us by the exponentially increasing powers of the digital age" $(2016,8)$. Moreover, just-in-time models are currently used not only in acquisitions (e.g., patron-driven or demand-driven acquisitions) but also in public services (e.g., triaged reference services; just-in-time information-literacy oneshots, tutorials, and guides; and chat reference). As skills training for the workers of the "information society," information literacy itself was strategized "just in time" for librarians to legitimate their role as educators in the new economy (Behrens 1994; Drabinski 2014; Kapitzke 2003; O’Connor 2009).

Just-in-time service is a key feature of NPM (Hood 1991). Quinn (2000) and Nicholson (2015) further consider NPM in academic libraries to be a form of "McDonaldization" (Ritzer 1993), a process of bureaucratic rationalization characterized by efficiency, predictability, calculability, and control. Mirza and Seale $(2017,185)$ argue that decontextualized pedagogical approaches, including just-in-time interventions such as tutorials and library guides, "often framed as more convenient and appealing to patrons," present technocratic, cost-efficient, and simplistic solutions "to the complex social problem of education." We note that some information-literacy 
instruction not connected to an immediate information need, such as orientations and tours, can be considered pre-emptive "just-in-case" risk-managing pedagogical interventions.

\section{Just-in-Case: Academic Libraries and Risk Management}

The second temporal order characteristic of the contemporary academic library is what we will call the present-future of just-in-case, the time of risk management, value, and innovation. Studies on the time of organizations suggest that management is a future-based process continually actualized and adjusted in the present (Whipp, Adam, and Sabelis 2002). Organizational planning and development are accomplished in reference to the future (although they may be motivated by past experiences), but the "concrete steps" of actualizing future visions "can only take place in the time horizon of the present" (Noss 2002, 55-56). Nonetheless, and somewhat paradoxically, the present is trivialized, treated as "a homogeneous and undifferentiated point on a linear time axis," of concern only as "the starting point of all planning endeavor" (Noss 2002, 50). As Drabinski states in reference to time and professional identity, "For librarianship, the present is always exceptional and always requires exceptional attention to take action for the coming future" $(2016,28)$. This future-oriented timescape is characterized by risk management and technological innovation.

\section{The Institutionalization of Library Learning Analytics}

Library learning analytics are one of the more recent sites through which librarianship produces the temporalities of just-in-time and the present-future. Individual scholars and practitioners have been studying library learning analytics for several years, and more recently, professional associations, namely, the ARL and the Association of College and Research Libraries (ACRL), have intervened into the discussion. The intervention of such organizations is of particular significance in that it instantiates the institutionalization of library learning analytics since the authority and influence of these organizations, and their support for library learning analytics, makes it difficult for individual academic libraries and librarians to dismiss analytics or to seek alternative means by which to demonstrate library value.

The recent work of Oakleaf, author of the ACRL's Value of Academic Libraries Report, is also key to the institutionalization of learning analytics. This work relies on and produces a sense of present-futureness while promoting just-in-time and just-in-case interventions. For example, in 2016, Oakleaf and Brown gave a presentation entitled "Institutional Learning Analytics: How Can Academic Libraries Connect?" at the Coalition for Networked Information Fall membership meeting. Their slides included the following graphic, originally produced by Gartner (Laney 2012), which makes explicit the connections between time, learning analytics, and return on investment (Oakleaf and Brown 2016).

\section{<INSERT figure 1 here>}

Figure 1. Gartner's Analytics Ascendency Model (Laney 2012, as cited in Oakleaf and Brown 2016). Courtesy of Gartner.

According to this graphic, at the rudimentary "descriptive" level, learning analytics provide information about the learning environment and the actions of the learners. Descriptive learning 
analytics are retrospective: they tell us what happened but not why it happened. At the "diagnostic" level, learning analytics monitor student performance in order to provide insight into what may be "facilitating or hindering student success" (Oakleaf 2016, 472). They operate in a continuous present. The "predictive" level of learning analytics, the level at which they are currently being developed in higher education, is "the ability to accurately predict future outcomes using learning data" (ECAR ANALYTICS Working Group 2015, 2, quoted in Oakleaf 2016, 472). Predictive analytics are fundamentally future-oriented. Drawing further on work by the ECAR ANALYTICS Working Group, Oakleaf argues that this "intelligence" allows stakeholders to implement just-in-time interventions "as a means to achieve more desirable final [future] outcomes" (ECAR ANALYTICS Working Group 2015, 2, quoted in Oakleaf 2016, 472). Finally, at the "prescriptive" level (not yet a reality, only a future promise), learning analytics "suggest specific interventions and actions known to aid learners" in order to "optimize student performance" (Oakleaf 2016, 472). Specific, real-time interventions in the present enhance future performance. Through the use of analytics, we can, in the present, predict and thereby control the future. Analytics direct us toward the future and away from the past and history.

The positive slope on the graph (Oakleaf and Brown 2016) indicates a correlation between the development of learning and the business value or "competitive advantage" gained by the institution. ${ }^{3}$ In a 2016 EDUCAUSE column, DePaul writes,

If instituted successfully, learning analytics could be considered the golden goose of higher education. . . . The implications here are that learning analytics can serve to reshape the trajectory of the student experience, enabling institutions to improve upon their offerings and, in turn, impact their overall academic standing. If students are succeeding and a college or university's reputation is thereby strengthened, such outcomes could serve to positively impact retention, future enrollment, and ultimately, an institution's bottom line. (2016, n.p.)

Analytics, although practiced in the present, are always already about the future; they force discussion and action into the temporality of the present-future. The slope also indicates that as learning analytics evolve, so does the intensity of surveillance and intervention. The future successful student, alumnus, knowledge worker, or potential donor is actively produced through an ongoing series of just-in-time interventions. What the graph does not show is that as surveillance increases, student agency - the ability to resist these interventions (Hathcock, 2018)—decreases.

Oakleaf also explicitly connects library learning analytics to the idea of just-in-time: "Many learning analytics systems attempt to predict, based on known attributes, which students are 'at risk' so that educators can intervene quickly" $(2016,472)$. Oakleaf goes on to suggest that the goals of learning analytics are consistent with managing institutional risk and uncertainty and

${ }^{3}$ We note that the word "business" does not appear before "value" in all versions of the Gartner image that appear on the Web. Moreover, in some versions, "data sophistication" is replaced by "difficulty." We further note that Gartner has long retired the report this graphic appears in; it is designated as "Archived" and accompanied by the note "This research is provided for historical perspective; portions may not reflect current conditions" (Laney 2012). 
that the future simply is learning analytics, whether librarians agree or not: "Be ready! Higher education is moving inexorably in the direction of using data to advance student success, and learning analytics is a linchpin toward this end" $(2016,474)$.

The language of library learning analytics in one of both inevitability and necessity, the only possible response to the crisis of higher education. In The Politics of Possibility, Amoore argues that "society has come to understand itself and its problems in terms of risk management" (2013, 7). Risk is constructed and performative, and the various technologies that have been devised to manage it "have, at their heart, a particular relationship to the future. They hold out the promise of managing uncertainty and making an unknowable and indeterminate future knowable and calculable" (7). Risk technologies rely on unknown future possibilities "according to a possibilistic logic" (12).

Risk is ubiquitous, and risk technologies seek to manage all possibilities; they function within a temporality of just-in-case. The dominant discourse around library learning analytics generally participates in and reproduces the risk technologies that Amoore describes, albeit with a somewhat different end goal. It relies on the sense that libraries and higher education are in a moment of crisis. Just-in-case requires educators to keep all avenues open and seize all opportunities to collect data. The result is a permanent state of surveillance, the continuous scanning and identification of new quantifiable and uniform data points, which provides universities and libraries persuasive, standardized numbers with which to demonstrate their value. According to Hursh and Wall, the aim of developing "measurement and accountability systems that commodify higher education" $(2011,560)$ is not primarily intended to help "higher education in meeting its own goals or indirectly stated objectives associated with the public good; rather it is a push to use assessment to hold higher education accountable to neoliberal goals" (564). These neoliberal goals are the constantly shifting measures of market success.

Library learning analytics represent more than a desire to know and control the future in the face of uncertainty; they offer the actual possibility of so doing. The predictive mode that pervades dominant discourses of librarianship, including recent discussions of library learning analytics, are not about trying to make sense of the past but about trying to predict and shape the future in the ongoing moment of the present. The question of student learning, let alone how academic libraries might contribute to it, is riven with uncertainty. This fundamental issue, however, is simply dismissed as a minor obstacle in the path toward the future promise of learning analytics. It is promise, not proof, that matters; it is doing something now, in preparation for the future, that counts. Analytics that reveal correlations sweep away uncertainty (and complexity) and the future can be known. That future is "ever-increasing amounts of learning analytics data," the inexorable "collection of greater amounts of information," and library "access to more complex and more revealing information about student library activity and interactions as well as campus level learning analytics" (Oakleaf 2015, 357-58). These are uncertain possibilities, but library learning analytics, as risk technologies, manage that uncertainty and construct the future as something knowable. The appeal of risk technologies such as library learning analytics is that they seem to mitigate crisis. It's important to be seen to be doing something, even if we presently lack "the connections, skills, confidence, interest, and ability," as Oakleaf claims $(2015,358)$. 


\section{Institutionalizing Analytics in the Present-Future}

We turn now to Academic Library Impact: Improving Practice and Essential Areas to Research produced by the ACRL in partnership with OCLC Research. This document seeks to tie library learning analytics to strategic planning. The research consists of numerous pieces: a report (literature review, focus groups with library administrators, interviews with provosts); a research agenda "based on those findings" (ACRL 2017, 1); an online visualization; and two bibliographies (works analyzed and works cited). The research agenda has six "priority areas," two of which directly address library learning analytics: "Priority 3: Include library data in institutional data collection" and "Priority 4: Quantify the library's impact on student success" (1). Each priority area is accompanied by "future-focused research questions" (2).

Both Priority 3 and Priority 4 introduce new time horizons for interventions and surveillance, beyond the time/space of the student's collegiate experience and the campus. One of the "suggested actions" for Priority 3 is to "include 'nontraditional' metrics that show how libraries support goals such as student recruitment and alumni engagement" (ACRL 2017, 4). For Priority 4 , these include examining "factors that affect student success before students begin their education at a college or university" and partnering "with outside stakeholders, such as businesses, to identify factors that influence student success following their undergraduate education" (6). Here the past and the future of the student's endeavors are of significance only insofar as they relate to the present-future of the library, and only insofar as the student represents economic value.

Priority 4 reinscribes and legitimates neoliberal ideas about value, even when there are questions about the ethics of the data collection: librarians are exhorted to "pull the sort of data to track user behaviors that library administrators and staff have shied away from in the past" (ACRL 2017, 55). Indicators and factors are data points for analytics, and the student is now "the 'dividual,' a fractionated subject whose risk elements divide her even within herself" (Amoore 2013, 8). Selwyn notes that proliferation of data disciplines individuals, producing "docility" and "administrative identities" $(2014,59)$. The research questions for further study, which explore how various library resources and services affect student success, are only those questions that can be answered through analytics. The emphasis on quantification and the imperative to consider student success as defined by "businesses" reproduces neoliberal notions of value as primarily economic and erases alternative, unquantifiable understandings of success (ACRL 2017, 6).

Academic Library Impact is also pervaded by a language of inevitability and a future foretold: "Now, more than ever"; "As academic libraries strategically evolve"; "As institutions gradually come to resemble each other" (ACRL 2017, 1-3). Inevitability is not limited to language however. The outcomes of the report were also predetermined by the methodology used to create the report. In its Request for Proposals for this research project, the ACRL specified that several of its own documents, namely, the 2010 VAL Report (Value of Academic Libraries), the Assessment in Action (AiA) projects, the 2015 Environmental Scan, and the "2016 Top Trends in Academic Libraries" (ACRL 2017, 14-15; ACRL 2016, 4-5) form the basis of the codebooks that were then used to analyze and code articles and reports that aligned with the themes already identified by the Request for Proposal. This formed the basis of the literature review section of the report. According to the codebooks, "any library collection, space, or service objectively tied 
to a particular grade or outcome" was coded as "success"; those that "did not have a measured or measurable effect on the student or their success" were coded as "teaching and learning" (ACRL 2017, 18, original emphasis). "Objectively" was used to describe variables that were "measurable and usually quantifiable" (ACRL 2017, 18). In this way, success was, and continues to be, defined in terms of the data points that constitute library learning analytics, while other, unmeasurable or unquantifiable effects by definition are not "success." Learning analytics themselves come to be included in the report, not due to their emergence from any of the three different data sources, but based on "feedback for the initial report draft, in advisory group brainstorming Academic Library Impact sessions, and by recent ACRL initiatives, such as the Learning Analytics e-Learning webcast series and ARL's Statistics Data Analytics" (ACRL 2017, 43-44). The reasoning here exemplifies tautology. Learning analytics were included because the ACRL wanted them to be included. This is an ideological and political intervention disguised by exhaustive amounts of data and the veneer of empiricism.

Academic Library Impact (ACRL 2017) seeks to remove risk and uncertainty from the future of academic libraries and, through a battery of both qualitative and quantitative research methods, make it knowable and calculable. The risk technologies dealing with library learning analytics make this move within the present-future timescape. In the creation of ever-increasing numbers of data points, indicators, and factors associated with individual students, library learning analytics seek to remove individual students from their own histories and trajectories, to erase those histories and control those trajectories. In seeking to control the future while insisting on the necessity of that control in a present time of crisis, discourses around library learning analytics erase both historical contexts and both choice of and responsibility for futures. Risk technologies, which remove individual subjects from their histories through a specification of data points, and construct and control the future through the creation of and response to possibilities, exist within the timescape of contemporaneity (Osborne 2013). The ways in which we talk about library learning analytics, which dissociate students from their history and academic libraries from their institutional and historical contexts, in order to remove uncertainty from and already know our future (and in this case, there is just one rather than an array of possibilities) embraces the timescape of the present-future, of contemporaneity and, in so doing, seeks to ignore politics and power.

In the preceding section, we have examined how, in documents issued by professional associations such as the ARL and the ACRL, the organizational timescape of learning analytics is marked both by just-in-time and just-in-case logics. In the next, and final section, we examine the particular ways that learning analytics work against social justice initiatives in higher education and interpellate students as future entrepreneurs and flexible, resilient, and docile subjects.

\section{Learning Analytics, Time, and the Performance of Neoliberal Subjectivities}

As we have seen above, mainstream professional discourse suggests that libraries' participation in campus efforts to collect data are fundamental to student success, thereby demonstrating library value. However, the intractable focus on quantifiable data makes it easier to sidestep complex social issues, including (in)equity and power, and culturally constructed sites of oppression such as race, class, gender, sexuality, and disability (Lovern 2018). Zerquera et al. 
note that "benchmarks that overemphasize quantitative data for ease of comparison often fail to account for social justice outcomes and provide metrics that inhibit the methodological creativity possible" $(2018,18)$. This is especially true when our students come from marginalized groups. To reduce learning, as messy as it is - and the student experience, as messy as it is - down to numbers and algorithms serves neither our students nor our pedagogical aims.

The focus on what is quantifiable and measurable in the present moment in order to construct a known future erases structural inequities, individual histories, and difference. Sharma argues that the meaning of an individual's own time and experiences of time "is in large part structured and controlled by both the institutional arrangements they inhabit and the time of others-other temporalities" $(2014,8)$. It is no surprise that what we measure, how we measure, and the interventions we use to "correct" the performance measured align with this form of hegemony. As Watters points out, "algorithms are not merely informative, they are extra-judicial": they identify and target "problem" or "at-risk" students to receive these interventions (2017). Contrary to social justice imperatives, "the focus is not on supporting all students, but rather only those judged as worthy of faculty and staff investment," sometimes leading to "proposed policies and solutions that seek to only address assessment results through the elimination of 'inputs' (or students who are perceived as the problem)" (Dorimé-Williams 2018, 46). If our instruction must be designed in line with algorithms that determine certain students to be "failing," we are complicit in creating a two-tiered system that offers less structured inquiry for those who are "succeeding" and a deficit-based banking model of education as a quick, anxiety-based fix for those deemed to be "failing" (Pagowsky 2015). Anxiety and fear of the future may prevail if academic libraries are beholden to campus efforts to use student data to demonstrate value, pushing librarians toward a pedagogy centered in the development of measurable skills.

Gourlay (2017) describes how, in discourses surrounding student engagement in higher education, that which is less visible is often considered less important. For example, more passive learning behaviors of students are seen as antithetical to learning, whereas more active behaviors are equated with engagement. In this sense, student engagement becomes performative. Because that which is invisible cannot easily be measured, primacy is given to the performative, the quantifiable, the assumed. When we seek to demonstrate that use of the library or participation in library instruction improves student grade point average (GPA), for example, we sidestep the messiness of students' experiences, including their experiences as learners. Many factors, past and present, influence student success in a course or a program of study, and it is imperative that we remain cognizant that success does not result only from that which is perceptible and measurable.

Using data to help our students to course correct saves (institutional) time. It also erases students' identities, histories, and temporalities, reinscribing racial, class, and gender norms. The very idea of a meritocracy, a primary narrative in higher education and deeply entrenched in Western society, depicts a level playing field where everyone starts out equal—all students begin with the same opportunities to succeed or fail. This is not true, of course, yet meritocracy — and neoliberalism - imply that structural inequalities and social injustice do not factor into success, and that success is easily achieved through simple hard work, competition, and constant skills development (investment in one's human capital). In the words of Gourlay, this "apparently benign discourse 'wears the clothes' of progressivism, but could be critiqued for offloading the 
responsibility onto the student and indirectly reinforcing the marketised view that the student carries the sole responsibility for their learning as a customer who makes a financial investment for personal gain" $(2017,29)$. Paltrinieri likens this discourse to "proficiency racism," namely, a skills market that excludes anyone "unable to play the game," who threaten neoliberal societies by not engaging in competition and not improving, nor appraising, oneself $(2017,469)$.

In line with Amoore (2013), the focus here is risk-anxiety, but through an anxiety of unemployment risk to streamline assessment practices and interpretation. The intent is to erase both anxiety and risk by finding assessment results that will nearly guarantee future employment so that present actions can be predetermined. This is what campus, and library, expectations for students become, where their behaviors, thoughts, desires, and whole selves need to be fully transparent so that we can personalize and help them achieve "their" goals through present actions. And whereas the possibilities seem fluid, they remain predetermined, like the outcomes of a choose-your-own adventure narrative. There is the illusion that many options exist and the direction one takes is based on free choice, but the pathways and destinations are always already determined. The success of analytics requires the learner to be flexible in order to meet the fluid definition of success at the institutional level (which is also based on the approaches the most privileged students take to be successful). Following a recipe of a certain selection of skills at a particular level of "excellence" will then "save" these less-privileged, struggling students. (Readings 1997) convincingly argues that in contemporary higher education, "excellence" is an empty signifier, one that can be endlessly deployed to take on any desired meaning as needed.

\section{Just-in-Time and Grit? The Appearance of Doing the Right Thing}

Narratives of resilience and grit, increasingly pervasive in higher education, can also be associated with the surgical, just-in-time interventions of learning analytics. Organizations such as the OECD, the World Bank, the IMF, and the UN have used resilience to advance a neoliberal agenda (Neocleous 2013), one that encourages individuation, naturalizes and depoliticizes systemic inequalities, normalizes insecurity, and places additional demands on white women and people of color (Galvan, Berg, and Tewell 2017). This discourse allows "the systemic causes of oppression and inequity to continue unquestioned and unchallenged" by eliminating "any sense of unity and support for addressing these issues at their roots" (Winkelstein and Terrile 2017, n.p.). It masks the impact of structural inequities; for example, poverty has a greater role in individual achievement than effort. Academic success does not automatically alleviate poverty (Stokas 2015). Normative and normalizing pedagogical interventions such as standardized tests and "neutral" analytics lead the individual to believe that the challenges they face stem from an intrinsic deficit rather than structural inequities, racism, classism, sexism, or ableism (Stokas 2015; Morley and Lugg 2009; Liu 2011). As with any hegemonic narrative, this invisible power structure overlays our work and actions whether we realize it or not. The student data we collect and the interventions we provide will be designed with the grit narrative baked in. Consider, then, the question, Are these algorithms and associated interventions in place to provide greater support for students to truly succeed, or are they just empty words of advice for retaining tuition dollars? For example, data may indeed show that successful students use the library to study for a given number of hours per week, but such data is of little help to a student struggling with food scarcity and time poverty that comes from a need to work full time while in school (Fisher 2018; Hope Center 2018). Implicit in this data is the suggestion that students should learn to endure 
suffering and forego other needs in order to engage in more successful academic behaviors. Narratives of grit and resilience arise because tangible and systemic supports are missing from our interventions, and this legitimizes suffering without requiring institutions of higher education to help their struggling students beyond data-driven "personalized" suggestions.

Library learning analytics, and learning analytics more broadly, function by constructing a singular notion of the student as learner. The learner comes to higher education and the academic library without a history or a present, and their future trajectory is limited to that of the flexible, resilient future worker (and hopefully, for institutions of higher education and academic libraries, potential donor). Library learning analytics, as described and institutionalized by organizations such as the ARL and ACRL, emphasize quantifiable notions of success. The need to collect data to quantify success reduces learning to performance and the acquisition of skills.

\section{Conclusion: Whose Future Are We Imagining?}

In this essay, we have argued that library learning analytics function within two dominant timescapes: just-in-time and just-in-case. Library learning analytics represent one way in which librarianship has recently sought to manage risk through technological innovation by producing just-in-time and just-in-case temporalities. The emergence of librarianship as a profession is marked by the temporal practices of Taylorism and scientific management. With the emergence of new information and communication technologies (ICTs), supply-chain innovation, and the advent of "the network society" (Castells 1996), libraries turned to just-in-time service models. This temporality, connected to a sense of acceleration, constant change, and crisis, continues to pervade mainstream discourse around librarianship and the future of libraries. At the same time, librarianship, as a profession plagued with self-doubt, exists in a decontextualized present-future, outside of past and present, oriented toward the future. In this present-future, just-in-case strategies mitigate the risk of a library-less future through an emphasis on and embrace of technological innovation and demonstrated "value."

Library learning analytics represent one way in which librarianship has recently sought to manage risk through technological innovation by producing just-in-time and just-in-case temporalities. They afford libraries the possibility of managing the risks of the future through ongoing just-in-time interventions. Library learning analytics, and learning analytics more broadly, work by constructing an idealized learner, detached from history, with a defined trajectory in higher education and a predetermined future as knowledge worker. Examining the temporalities and subjectivities produced and reproduced in the discourse around library learning analytics reveals that this discourse erases questions of power, politics, and history, and works against social justice. In describing what the future $i s$, rather than what it could or should be, this discourse, this "failure to imagine that libraries can do more than serve the quotidian needs of higher education" (Coysh, Denton, and Sloniowski 2018, 126), erases our ability to shape our futures, and our responsibility for so doing. This essay, in its attempts to unpack the relations of power embedded in the temporalities of library learning, seeks to reclaim some of this agency.

\section{Notes}

References 
ACRL (Association of College and Research Libraries). 2010. Value of Academic Libraries: A Comprehensive Research Review and Report. Researched by Megan Oakleaf. Chicago: Association of College and Research Libraries.

https://www.ala.org/acrl/sites/ala.org.acrl/files/content/issues/value/val_report.pdf.

- 2016. Request for Proposals: Action-Oriented Research Agenda on Library

Contributions to Student Learning and Success. https://acrl.ala.org/value/wp-

content/uploads/2016/04/ACRL-RFP-for-action-oriented-research-agenda.pdf.

- 2017. Academic Library Impact: Improving Practice and Essential Areas to Research. Prepared by Lynn Silipigni Connaway, William Harvey, Vanessa Kitzie, and Stephanie Mikitish of OCLC Research. Chicago: Association of College and Research Libraries.

https://www.ala.org/acrl/sites/ala.org.acrl/files/content/publications/whitepapers/academiclib.pdf.

Adam, Barbara C. 1990. Time and Social Theory. Oxford: Polity Press.

Routledge.

1998. Timescapes of Modernity: The Environment and Invisible Hazards. London:

Amoore, Louise. 2013. The Politics of Possibility: Risk and Security beyond Probability.

Durham, NC: Duke University Press.

ARL (Association of Research Libraries). 2016. Strategic Thinking and Design Initiative. Extended and Updated Report. Washington, DC: Association of Research Libraries. https://www.arl.org/storage/documents/publications/arl-strategic-thinking-and-design-initiativeextended-and-updated-report-june2016.pdf.

Bansel, Peter, and Bronwyn Davies. 2005. "The Time of Their Lives? Academic Workers in Neoliberal Time(s)." Health Sociology Review 14 (1) (March): 47-58.

https://doi.org/10.5172/hesr.14.1.47.

Becker, Joseph. 1979. "Libraries, Society and Technological Change." Library Trends 27 (3): 409-16. https://www.ideals.illinois.edu/bitstream/handle/2142/7041/librarytrendsv27i31_opt.pdf.

Behrens, Shirley J. 1994. "A Conceptual Analysis and Historical Overview of Information Literacy.” College \& Research Libraries 55 (4): 309-22. https://doi.org/10.5860/crl_55_04_309.

Bossaller, Jenny, Christopher Sean Burns, and Amy VanScoy. 2017. "Re-Conceiving Time in Reference and Information Services Work: A Qualitative Secondary Analysis." Journal of Documentation 73 (1) (January): 2-17. https://doi.org/10.1108/JD-03-2016-0028.

Bowles-Terry, Melissa. 2012. "Library Instruction and Academic Success: A Mixed-Methods Assessment of a Library Instruction Program." Evidence Based Library and Information Practice 7 (1): 82-95. https://doi.org/10.18438/B8PS4D. 
Brown, Sherri, Charlie Bennett, Bruce Henson, and Alison Valk. 2014. Next-Gen Learning Spaces. SPEC Kit 342. Washington, DC: Association of Research Libraries. https://doi.org/10.29242/spec.342.

Carrigan, Dennis P. 1996. "Commercial Journal Publishers and University Libraries: Retrospect and Prospect." Journal of Scholarly Publishing 27 (4): 208-21.

Castells, Manuel. 1996. The Rise of the Network Society. Malden, MA: Blackwell.

Clegg, Sue. 2010. "Time Future - the Dominant Discourse of Higher Education." Time \& Society 19 (3): 345-64. https://doi.org/10.1177/0961463X10381528.

Closet-Crane, Catherine. 2011. "A Critical Analysis of the Discourse on Academic Libraries as Learning Places." Advances in Library Administration and Organization 30:1-50. https://doi.org/10.1108/S0732-0671(2011)0000030004.

Coysh, Sarah J., William Denton, and Lisa Sloniowski. 2018. "Ordering Things.” In The Politics of Theory and Practice of Critical Librarianship, edited by Karen P. Nicholson and Maura Seale, 129-44. Sacramento, CA: Library Juice Press.

DePaul, Kristi. 2016. "The State of Learning Analytics." Transforming Higher Ed (blog), EDUCAUSE Review. Last modified November 17, 2016. https://er.educause.edu/blogs/2016/11/the-state-of-learning-analytics.

DeVault, Marjorie L. 2008. People at Work: Life, Power, and Social Inclusion in the New Economy. New York: New York University Press.

Dorimé-Williams, Marjorie. 2018. "Developing Socially Just Practices and Policies in Assessment." New Directions for Institutional Research 177:41-56. https://doi.org/10.1002/ir.20255.

Drabinski, Emily. 2014. "Toward a Kairos of Library Instruction.” Journal of Academic Librarianship 40 (5): 480-85. https://doi.org/10.1016/j.acalib.2014.06.002.

2016. "Becoming Librarians, Becoming Teachers: Kairos and Professional Identity." Canadian Journal of Information and Library Science 40 (1): 27-36. https://muse.jhu.edu/article/611575.

- 2017. "A Kairos of the Critical: Teaching Critically in a Time of Compliance." Communications in Information Literacy 11 (1): 76-94. https://doi.org/10.15760/comminfolit.2017.11.1.35.

Ferlie, Ewan, Christine Musselin, and Gianluca Andresani. 2008. "The Steering of Higher Education Systems: A Public Management Perspective." Higher Education 56 (3): 325-48. https://doi.org/10.1007/s10734-008-9125-5. 
Fisher, Zoe. 2018. "Libraries \& Learning Analytics: A Brief History.” Zoe Fisher (website). Last modified March 5, 2018. https://quickaskzoe.com/2017/11/10/libraries-learning-analytics-abrief-history/.

Gaha, Ula, Suzanne Hinnefeld, and Catherine Pellegrino. 2018. "The Academic Library's Contribution to Student Success: Library Instruction and GPA." College \& Research Libraries 79 (6): 737-46. https://doi.org/10.5860/crl.79.6.737.

Gaines, Ayanna. 2014. “That's Women's Work: Pink-Collar Professions, Gender, and the Librarian Stereotype." In The Librarian Stereotype: Deconstructing Perceptions and Presentations of Information Work, edited by Nicole Pagowsky and Miriam Rigby, 85-109. Chicago: Association of College \& Research Libraries Press.

Galvan, Angela, Jacob Berg, and Eamon Tewell. 2017. "Resilience, Grit, and Other Lies. Academic Libraries and the Myth of Resiliency." Paper presented at the Association of College \& Research Libraries Annual Conference, Baltimore, MD, March 22-25, 2017. https://eamontewell.files.wordpress.com/2008/03/resilience-grit-and-other-lies-acrl-2017.pdf.

Giroux, Henry A., and Susan Searls Giroux. 2004. Take Back Higher Education: Race, Youth, and the Crisis of Democracy in the Post-Civil Rights Era. New York: Palgrave.

Gourlay, Lesley. 2017. “Student Engagement, 'Learnification' and the Sociomaterial: Critical Perspectives on Higher Education Policy." Higher Education Policy 30:25-34. https://doi.org/10.1057/s41307-016-0037-1.

Harris, Roma M. 1992. Librarianship: The Erosion of a Woman's Profession. Norwood, NJ: Ablex.

Hartman, Yvonne, and Sandra Darab. 2012. "A Call for Slow Scholarship: A Case Study on the Intensification of Academic Life and Its Implications for Pedagogy." Review of Education, Pedagogy, and Cultural Studies 34:49-60. https://doi.org/10.1080/10714413.2012.643740.

Harvey, David. 1989. The Condition of Postmodernity: An Enquiry into the Origins of Cultural Change. Malden, MA: Blackwell.

- 2007. A Brief History of Neoliberalism. New York: Oxford University Press.

Hathcock, April. 2018. "Learning Agency, Not Analytics." At the Intersection (blog). Last modified January 24, 2018. https://aprilhathcock.wordpress.com/2018/01/24/learning-agencynot-analytics/.

Hermann, Christopher. 2015. Capitalism and the Political Economy of Work Time: Frontiers of Political Economy. New York: Routledge, 2015. 
Hicks, Deborah. 2014. "The Construction of Librarians' Professional Identities: A Discourse Analysis." Canadian Journal of Information and Library Science 38 (4) (December): 251-70. https://doi.org/10.1353/ils.2014.0017

Hicks, Deborah, and Theresa J. Schindel. 2016. "Time Changes Things: Time as a Linguistic Resource for Professionals in Information-Intensive Fields." Canadian Journal of Information \& Library Sciences 40 (1) (March): 1-26. https://muse.jhu.edu/article/611574/pdf.

Hood, Christopher. 1991. "A Public Management for All Seasons?” Public Administration 69 (1) (March): 3-19. https://doi.org/10.1111/j.1467-9299.1991.tb00779.x.

Hood, Christopher C., and Michael W. Jackson. 1991. "The New Public Management: A Recipe for Disaster." Canberra Bulletin of Public Administration 64 (May): 16-24.

Hope Center for College, Community, and Justice. 2018. Basic Needs Security among Students Attending Georgia Colleges and Universities. Report released October 15, 2018. https://hope4college.com/wp-content/uploads/2018/10/GeorgiaSchools-10.16.2018.html.

Hursh, David, and Andrew F. Wall. 2011. "Repoliticizing Higher Education Assessment within Neoliberal Globalization." Policy Futures in Education 9 (5): 560-72. https://doi.org/10.2304/pfie.2011.9.5.560.

Jantti, Margie, and Brian Cox. 2013. "View of Measuring the Value of Library Resources and Student Academic Performance through Relational Datasets." Evidence Based Library and Information Practice 8 (2): 163-71. https://doi.org/10.18438/B8Q89F.

Jantti, Margie, and Jennifer Heath. 2016. "What Role for Libraries in Learning Analytics?" Performance Measurement and Metrics 17 (2): 203-10. https://doi.org/10.1108/PMM-04-20160020 .

Jones, Kyle M.L., and Dorothea Salo. 2018. "Learning Analytics and the Academic: Professional Ethics at a Crossroads." College \& Research Libraries 79 (3): 304-23.

https://doi.org/10.5860/crl.79.3.304.

Kapitzke, Cushla. 2003. "Information Literacy: A Review and Poststructural Critique." Australian Journal of Language and Literacy 26 (1): 53-66.

Kont, Kate-Riin. 2013. "Cost Accounting and Scientific Management in Libraries: A Historical Overview." Journal of Management History 19 (2) (April): 225-40. https://doi.org/10.1108/17511341311307390.

Laney, Douglas. 2012. Big Data Strategy Components: IT Essentials. Published October 15, 2012. Gartner. https://www.gartner.com/en/documents/2197515-big-data-strategy-componentsit-essentials. 
Liu, Amy. 2011. "Unraveling the Myth of Meritocracy within the Context of US Higher Education." Higher Education 62 (4): 383-97. http://doi.org/10.1007/s10734-010-9394-7

Lovern, Lavonna L. 2018. "Pedagogical Primer." In Fostering a Climate of Inclusion in the College Classroom: The Missing Voice of the Humanities, 1st ed., 15-32. Cham, Switzerland: Palgrave MacMillan.

Lynch, Beverly P. 1979. "Libraries as Bureaucracies." Library Trends 27 (3): 259-67. http://hdl.handle.net/2142/7034.

Matus, Claudia, and Susan Talburt. 2015. "Producing Global Citizens for the Future: Space, Discourse and Curricular Reform." Compare 45 (2): 226-47.

https://doi.org/10.1080/03057925.2013.842682.

Menzies, Heather, and Janice Newson. 2007. 'No Time to Think: Academics' Life in the Globally Wired University." Time \& Society 16 (1): 83-98. https://doi.org/10.1177/0961463X07074103.

Mirza, Rafia, and Maura Seale. 2017. "Who Killed the World? White Masculinity and the Technocratic Library of the Future." In Topographies of Whiteness: Mapping Whiteness in Library and Information Science, edited by Gina Schlesselman-Tarango, 171-97. Sacramento, CA: Library Juice Press.

Morley, Louise, and Rosemary Lugg. 2009. "Mapping Meritocracy: Intersecting Gender, Poverty and Higher Educational Opportunity Structures." Higher Education Policy 22 (1): 3760. https://doi.org/10.1057/hep.2008.26.

Moss, Dorothy. 2006. Gender, Space and Time: Women and Higher Education. Lanham, MD: Lexington Books.

Neocleous, Mark. 2013. "Resisting Resilience.” Radical Philosophy 178 (1). https://www.radicalphilosophy.com/commentary/resisting-resilience.

Nicholson, Karen P. 2015. "The McDonaldization of Academic Libraries and the Values of Transformational Change." College \& Research Libraries 76 (3): 328-38. https://doi.org/10.5860/crl.76.3.328.

_ 2016. “Taking Back' Information Literacy: Time and the One-Shot in the Neoliberal University." In Critical Library Pedagogy Handbook. Vol. 1, Essays and Workbook Activities, edited by Kelly McElroy and Nicole Pagowsky, 25-39. Chicago: Association of College \& Research Libraries.

2019a. "On the Space/Time of Information Literacy, Higher Education, and the Global Knowledge Economy." Journal of Critical Library and Information Studies 2 (1). https://journals.litwinbooks.com/index.php/jclis/article/view/86/36. 
_. 2019b. "Time, New Public Management, and Canadian Academic Librarians' Scholarship and Service." Canadian Journal of Academic Librarianship 5 (May): 1-29. https://doi.org/10.33137/cjal-rcbu.v5.29888.

Nishimoto, Ikuko. 2002. "Cooperation Engineered: Efficiency in the 'Just-in-Time' System.” In Making Time: Time and Management in Modern Organizations, edited by Richard Whipp, Barbara C. Adam, and Ida Sabelis, 104-14. New York: Oxford University Press.

Noss, Christian. 2002. "Taking Time Seriously: Organizational Change, Flexibility, and the Present Time in a New Perspective." In Making Time: Time and Management in Modern Organizations, edited by Richard Whipp, Barbara Adam, and Ida Sabelis, 46-60. New York: Oxford University Press.

Oakleaf, Megan. 2015. “The Library's Contribution to Student Learning: Inspirations and Aspirations." College \& Research Libraries 76 (3): 353-58. https://doi.org/10.5860/crl.76.3.353.

- 2016. "Getting Ready \& Getting Started: Academic Librarian Involvement in Institutional Learning Analytics Initiatives.” Journal of Academic Librarianship 42 (4): 472-75. https://doi.org/10.1016/j.acalib.2016.05.013.

Oakleaf, Megan, and Malcolm Brown. 2016. "Institutional Learning Analytics: How Can Academic Libraries Connect?" Paper presented at the Coalition for Networked Information membership meeting, Washington DC, November 28, 2016. https://www.cni.org/wpcontent/uploads/2017/01/CNI_Library_Brown.pdf.

O'Connor, Lisa. 2009. "Information Literacy as Professional Legitimation: A Critical Analysis." Journal of Education for Library \& Information Science 50 (2): 79-89. https://doi.org/10.1108/00242530910978190.

Olssen, Mark, and Peters, Michael A. 2005. "Neoliberalism, Higher Education and the Knowledge Economy: From the Free Market to Knowledge Capitalism." Journal of Education Policy 20 (3): 313-45. https://doi.org/10.1080/02680930500108718.

Osborne, Peter. 2013. Anywhere or Not at All: Philosophy of Contemporary Art. London: Verso.

Pagowsky, Nicole. 2015. "A Pedagogy of Inquiry." Communications in Information Literacy 9 (2): $136-44$.

http://www.comminfolit.org/index.php?journal=cil\&page=article \&op=view\&path $\% 5 \mathrm{~B} \% 5 \mathrm{D}=\mathrm{v} 9 \mathrm{i}$ $2 \mathrm{p} 136$.

Paltrinieri, Luca. 2017. "Managing Subjectivity: Neoliberalism, Human Capital, and Empowerment." Fudan Journal of the Humanities and Social Sciences 10:459-71. https://doi.org/10.1007/s40647-017-0200-0. 
Payne, Phillip G., and Brian Wattchow. 2009. "Phenomenological Deconstruction, Slow Pedagogy, and the Corporeal Turn in Wild Environmental/Outdoor Education." Canadian Journal of Environmental Education 14:15-32. https://cjee.lakeheadu.ca/article/view/883.

Petrina, Stephen. 2004. "The Politics of Curriculum and Instructional Design/Theory/Form: Critical Problems, Projects, Units, and Modules.” Interchange 35 (1): 81-126.

https://doi.org/10.1023/B:INCH.0000039022.53130.d5.

Quinn, Brian. 2000. "The McDonaldization of Academic Libraries?” College \& Research Libraries 61 (3): 248-61. https://doi.org/10.5860/crl.61.3.248.

Readings, Bill. 1997. The University in Ruins. Cambridge, MA: Harvard University Press.

Rider, Fremont. 1936. "Library Cost Accounting.” Library Quarterly 6 (4): 31-81. http://www.jstor.org/stable/4302298.

Ritzer, George. 1993. The McDonaldization of Society: An Investigation into the Changing Character of Contemporary Social Life. Thousand Oaks, CA: Pine Forge Press.

Robertson, Susan L. 2009. "'Spatialising' the Sociology of Education: Stand-Points, EntryPoints, Vantage-Points." In The Routledge International Handbook of Sociology of Education, edited by Michael W. Apple, Stephen J. Ball, and Luis Armando Gandin, 1-16. New York: Routledge.

- 2010. "Challenges Facing Universities in a Globalising World." Paper presented at the International Seminar on Quality in Higher Education: Indicators and Challenges, Porto Alegre, Brazil, 2010. https://susanleerobertson.files.wordpress.com/2012/07/2010-robertsonchallenges.pdf

Selwyn, Neil. 2014. Distrusting Educational Technology: Critical Questions for Changing Times. New York: Routledge.

Sharma, Sarah. 2014. In the Meantime: Temporality and Cultural Politics. Durham, NC: Duke University Press.

Soria, Krista M., Jan Fransen, and Shane Nackerud. 2013. "Library Use and Undergraduate Student Outcomes: New Evidence for Students' Retention and Academic Success." portal: Libraries and the Academy 13 (2): 147-64. https://doi.org/10.1353/pla.2013.0010.

Spence, Lester K. 2015. Knocking the Hustle: Against the Neoliberal Turn in Black Politics. Brooklyn, NY: Punctum Books.

Stokas, Ariana Gonzalez. 2015. "A Genealogy of Grit: Education in the New Gilded Age." Educational Theory 65 (5): 513-28. https://doi.org/10.1111/edth.12130. 
Stone, Graham, and Bryony Ramsden. 2013. "Library Impact Data Project: Looking for the Link between Library Usage and Student Attainment." College \& Research Libraries 74 (6): 546-59. https://doi.org/10.5860/crl12-406.

Usher, Robin, and Richard Edwards. 2007. Lifelong Learning-Signs, Discourses, Practices. Dordrecht, Netherlands: Springer-Verlag.

Vyhnanek, Kay, and Christy Zlatos. 2011. Reconfiguring Service Delivery. SPEC Kit 327. Washington, DC: Association of Research Libraries. https://doi.org/10.29242/spec.327.

Walker, Judith. 2009. "Time as the Fourth Dimension in the Globalization of Higher Education." Journal of Higher Education 80 (5): 483-509. https://doi.org/10.1353/jhe.0.0061.

Watters, Audrey. 2015. "The History of the Future of Education.” Hack Education (blog). February 19, 2015. http://hackeducation.com/2015/02/19/the-history-of-the-future-of-education/

- 2017. "The Weaponization of Education Data." Hack Education (blog). December 11, 2017. http://hackeducation.com/2017/12/11/top-ed-tech-trends-weaponized-data.

Whipp, Richard, Barbara Adam, and Ida Sabelis. 2002. Making Time: Time and Management in Modern Organizations. Oxford: Oxford University Press.

Widdicombe, Richard P. 2004. "Evolution of a Revolution.” Science \& Technology Libraries 24 (1-2): 187-94. https://doi.org/10.1300/J122v24n01_12.

Williamson, Ben. 2016. "Digital Education Governance: Data Visualization, Predictive Analytics, and 'Real-Time' Policy Instruments. Journal of Education Policy 31 (2): 123-41. https://doi.org/10.1080/02680939.2015.1035758.

Winkelstein, Julie Ann, and Vikki Terrile. 2017. "Resilience_What's in a Word?" SRRT Newsletter Social Responsibilities Round Table 199 (June). http://libr.org/srrt/news/srrt199.php.

Wong, Shun Han Rebekah, and T. D. Webb. 2011. "Uncovering Meaningful Correlation between Student Academic Performance and Library Material Usage." College \& Research Libraries 72 (4): 361-70. https://doi.org/10.5860/crl-129.

Ylijoki, Oili-Helena, and Hans Mäntylä. 2003. "Conflicting Time Perspectives in Academic Work.” Time \& Society 12 (1): 55-78. https://doi.org/10.1177/0961463X03012001364.

Zerquera, Desiree, Kimberly A. Reyes, Jason T. Pender, and Ramy Abbady. 2018.

"Understanding Practitioner-Driven Assessment and Evaluation Efforts for Social Justice." New Directions for Institutional Research 177:15-40. https://doi.org/10.1002/ir.20254. 
Karen P. Nicholson is manager, Information Literacy, at the University of Guelph and a lecturer with the Faculty of Information and Media Studies at the University of Western Ontario. She holds an MA, MLIS, and a PHD (LIS). Her research interests include critical interdisciplinary approaches to space and time, information literacy, and critical university studies. She has published essays in College \& Research Libraries, the Journal of Critical Library and Information Studies, the Canadian Journal of Academic Librarianship, and The Critical Library Pedagogy Handbooks. Together with Maura Seale, Nicholson is coeditor of The Politics of Theory and the Practice of Critical Librarianship (Library Juice Press, 2018). She has worked in academic libraries since 2001.

Nicole Pagowsky is an associate librarian and instruction coordinator at the University of Arizona Libraries. She holds a second master's in instructional design and educational technology, with a specific interest in applying critical pedagogy practices to instructional design. She is coeditor of the two-volume set The Critical Library Pedagogy Handbooks, which received the ACRL Ilene F. Rockman Publication of the Year Award in 2017. Nicole also coedited The Librarian Stereotype: Perceptions and Presentations of Information Work in 2014; this title examined how librarians are perceived and how that affects numerous facets of our work. She has published and presented on these intersecting topics nationally, has been an invited instructor for ALA's Instructional Design Essentials ecourse, and currently teaches the course she designed on Information Literacy Pedagogy (LIS 581) for the University of Arizona School of Information.

Maura Seale is the History Librarian at the University of Michigan and was previously at Georgetown University. With Karen Nicholson, she recently coedited The Politics of Theory and the Practice of Critical Librarianship. Other recent scholarly work includes "Who Killed the World? White Masculinity and the Technocratic Library of the Future," in Topographies of 
Whiteness: Mapping Whiteness in Library and Information Science; and "Behavioral Expectations for the Mommy Librarian: The Successful Reference Transaction as Emotional Labor," in The Feminist Reference Desk: Concepts, Critiques, and Conversations. She has also written about critical pedagogy, discourses around race and gender, critical theory, and neoliberalism in regards to libraries and librarianship. 